\title{
Die laerskoolkind in die erediens
}

M J du P Beukes

Sentrum vir Teologiese Navorsing en Toerusting (Afd A)

Universiteit van Pretoria

\begin{abstract}
The primary school child in public worship

With this study I want to demonstrate that children, on the grounds of Biblical, dogmatical and church law are no less the property of God than adults. Because children are a complete part of God's church, they should be taken into account during public worship. The exceptional nature of the primary school child asks of the church to consider that parts of public worship be arranged for their specific needs and prepared according to their nature.
\end{abstract}

\section{INLEIDING}

'n Groot getal kinders verdwyn uit die kerk of raak kerklik onbetrokke nadat hulle belydenis van geloof gedoen het. Die oorsaak word oor die algemeen gesoek by die feit dat kinders in hulle finalejaarkategese nie doeltreffend gekatkiseer word nie. Die oorsaak lê waarskynlik baie dieper en kom op 'n baie vroeër stadium reeds voor. Die werklike probleem is waarskynlik die feit dat hulle in hulle vormingsjare nie as werklike deel van die gemeente beskou word nie en veral nie in die eredienste betrek word nie (Barnard 1988:352). Volgens Capon (1967:1) is dit doodgewoon diskriminasie wat teen die kinders in die erediens plaasvind:

There is no one in the whole Church more likely to be underestimated than the child. We have worked hard to overcome all the other distinctions between Christians in the body of Christ - distinction of colour, of class, of income and so on - but the distinction between adult and child remains firmly drawn. The child is a second - class citizen in the kingdom of God. We deny, in word and deed, that he is a full member of the Church. When we think of the Church members, we mentally exclude one of the largest groups off all - those under thirteen. 
Die erediens is die hart van kerkwees (Barnard 1981:13). Dit vind elke Sondag van die jaar plaas. In die meeste gemeentes twee keer per Sondag. In die geval van getroue lidmate woon die kinders die meeste van hierdie eredienste saam met hulle ouers by. Die bywoning van eredienste is vir hulle feitlik sinoniem met kerkwees. As hulle tydens die meeste van hierdie byeenkomste onbetrokke is, lei dit nie noodwendig net tot 'n negatiewe persepsie van eredienste nie, maar ook van kerkwees as sodanig.

Opvoedkundige navorsing toon dat kinders wat aanhoudend blootgestel word aan waarhede wat hulle nie begryp nie, op die dag waneer hy ryp genoeg is om dit wel te verstaan, geen betekenisvolle reaksie toon nie: eerder 'n verveelde houding omdat die oorbekende gegewens dan vir hulle trefkrag verloor het. Is hierdie eerste jare wat 'n kind dikwels verveeld in die erediens sit, nie miskien die rede waarom baie kinders later volkome onverskillig staan teenoor die erediens nie? (Van Loggerenberg 1982:37).

Baie redes kan genoem word waarom kinders nie by die erediens betrek word nie. Een van die vernaamste redes is waarskynlik die feit dat die kerk nie altyd ten volle rekening hou met die laerskoolkind se eie unieke aard nie en hom/haar gevolglik nie ooreenkomstig sy eie wese en aard in die erediens verreken nie. Van die liturgiek geld dieselfde as wat Thurneysen (1957:56) van die Sielsorg gesê het:

Sage mir, wie du über den Menschen denkst, und ich will dir sagen, was für ein Seelsorger du bist! Alle Verwirrungen in der Seelsorge lassen sich zurückfuhren auf ein mangelendes oder ein falsches Verstehen dessen was der Mensch ist. Für die Lehre von der Seelsorge ergibt sich von daher die Notwendigkeit einer Auseinandesetzung mit allem andersartigen Menschenverständnis.

Hierdie studie is 'n poging om die laerskoolkind te beskryf sodat spesifiek die Nederduitsch Hervormde Kerk groter begrip vir hierdie kinders, veral in die erediens sal hê. Die fokus val op die kind as sodanig en nie op 'n beskrywing van hoe hy/sy in die verlede en in die hede in die erediens betrek is en word nie.

Die volgende sake sal aan die orde gestel word: Wie is die laerskoolkind Bybelsdogmaties; kerkregtelik en psigologies-sosiologies gesien? In hierdie studie sal teologiese en ander wetenskappe se navorsing in verband met die mens na vore gebring word sonder om die een bo die ander te stel. Verskillende menswetenskappe is uit 'n bepaalde hoek met die mens besig. Nie een kan daarop aanspraak maak om die mens volledig te beskryf nie. Elkeen is slegs besig om 'n bepaalde faset van menswees te beklemtoon. Die resultate van hierdie wetenskappe vul mekaar dus aan - hulle is 
complementair ten opzichte van elkaar (Berkhoff 1969:10). Binne die matriks van 'n hermeneuties-kommunikatiewe handelingsteorie vir die Praktiese Teologie kan op 'n wetenskaplik verantwoorde wyse gekom word tot 'n Menschenkenntnis as die psigologiese en filosofiese visie op die mens en 'n Menschverständnis as die Bybelse verstaan van die mens (Coetzee 1996:26).

\section{BYBELS-DOGMATIESE GEGEWENS OOR DIE KIND IN DIE EREDIENS}

\subsection{Inleiding}

In 'n Bybels-dogmatiese besinning oor die kind in die erediens sal daar veral met twee aspekte rekening gehou moet word:

* Daar bestaan nie so iets soos 'n Bybelse antropologie wat net op die kind van toepassing is nie. Die Bybelse antropologie beskryf die mens as sodanig ... dit het daarom betrekking op die mens in al sy lewensfases. Dit wat normaalweg as Bybelse antropologie beskryf word, is net so van toepassing op die kind as op die volwassene.

* Hoewel die besinning oor wie die kind is, geplaas kan word binne die loci van die antropologie in die dogmatiese ensiklopedie, sal rekening gehou moet word met die feit dat daar feitlik nie een loci in die dogmatiek is wat nie die mens betrek nie. Die Godsleer, die Christologie, die Pneumatologie, die Ekklesiologie en die Eskatologie het implikasies vir die besinning oor die kind. 'Die Christelike leerstuk oor God en die Christelike leerstuk oor die mens hoort bymekaar. Die teologie het immers met die God te doen wat in sy openbaring toon dat hy 'n God vir ons wil wees' (Du Rand 1982:146).

\subsection{Die kind as geskape beelddraer van God}

Soos die res van die skepping is die mens deur God geskep. Die mens is egter as die kroon van die skepping geskep (Ps 8; Gen 2). Sy besondere posisie in die skepping maak hom 'n vry, selfstandige, verantwoordelike en afhanklike wese (Beukes 1993: 178). In sy verantwoordelikheid en vryheid word hy deur God aangespreek en besit gevolglik in sy menswees 'n normatiewe kapasiteit waarvan die gewete 'n integrale deel is en wat hom bestem om 'n aanspreekbare wese te wees. Aan die ander kant is die mens as afhanklike wese altyd kwesbaar en is en bly hy altyd ' $n$ wese met bepaalde gevoelens en verlanges. Hy bly altyd op God aangewese en kan alleen bestaan as mens saam met ander mense. 
Die mens is geskep as beeld van God (Gen 2:26). 'Net soos die mens se geskapenheid is dit ' $n$ konstante wat alle mense in gemeen het van hulle geboortedag: Ondanks status en voorkoms of ouderdom' (Robbertze 1995:2). Die Bybel gee nie vir ons 'n definisie van die begrip 'beeld van God' nie. Vir Heinrich Ott (1989:190) hou die begrip beeld van God verband met die mens se persoon-wees wat in die besonder kulmineer in die mens se vryheid, verantwoordelikheid en moontlikheid om iemand aan te spreek en self aangespreek te word.

Die oerfenomeen van menswees is daarom die mens se verhouding tot ander mense. Louw (1989:27) verstaan die begrip beeld van God nog baie breër. Beeld van God dui op die mens as verteenwoordiger van God binne die totaal van die syn veral met betrekking tot relasies: sy relasie met God, met homself, sy medemens, die kultuur, die natuur en alle strukture van die samelewing. Die begrip 'beeld van God' funksioneer veral sterk in die konteks van die mens as medemens en die mees intieme van hierdie medemenslikheid is die mens in sy heteroseksuele verhouding van man en vrou waaruit die huwelik en die gesin geskep word (Coetzee 1996:2). Beide die indikatief en die imperatief wat deur die geskep na 'die beeld' van God meebring, is van deurslaggewende betekenis wanneer daar besin word oor die kind in die erediens (Buitendag 1995:2).

\subsection{Die kind as verloste sondaar}

Net soos die volwassene is die kind sondaar (Nederlandse Geloofsbelydenis, artikel 15, Heidelbergse Kategismus, Sondag. 2-4; Doopformulier; Van Niftrik MCMLXI:95; Buitendag 1995:2; Robbertze 1995:2). Op verskeie plekke in die Bybel lees ons dat mense die neiging het om deur verkeerde keuses al die verhoudinge te versteur waarbinne hulle hulle bevind. Alle mense het deel aan die sonde van Adam en Eva, is van nature ongehoorsaam aan God en sy Woord en besit nie van nature die vermoë om te onderskei tussen goed en kwaad nie. As gevolg van hulle sondige natuur is al die versoekings op die pad vir hulle 'n wesenlike gevaar. Om erns te maak met mense en hulle natuurlike vermoëns, bring noodwendig mee dat hulle nooit te hoog aangeslaan mag word nie. Die beeld van die Bybel oor die mens is nooit te optimisties nie. Die mens verkeer volgens die Bybel nooit in 'n toestand van volkome homeostase nie (Louw 1989:20).

$\mathrm{Al}$ is mense sondaars buite hulle wete, bly hulle nog aanspreeklik vir hulle optrede. Die gelowige het deur Jesus Christus 'n nuwe skepsel geword wat nie alleen die verantwoordelikheid het om aan God gehoorsaam te wees nie, maar wat ook deur die krag van die Heilige Gees daartoe in staat is. Die mense wat sondaars is, is tegelyk begenadigde sondaars. Jesus Christus het vir al hulle sonde betaal, die dood vir hulle oorwin en hulle tot kinders van God gemaak. Deur Jesus Christus het volwassenes en kinders 
ten volle deel aan Christus en al sy weldade (Nederlandse Geloofsbelydenis, artikel 2023; Heidelbergse Kategismus, Sondag 5-31; Sondag 10 vraag 74; Van Niftrik MLX: 94; Buitendag 1995:2; Robbertze 1995:3; Beukes 1993:179). In die lig hiervan oordeel Louw (1989:20) dat die Bybelse beeld van die mens nie net pessimisties is nie, maar tegelyk ook optimisties. As Christus-gelowige is die mens ook 'n herskepte wese. Mense hoef nie eers volwasse te wees of te presteer om waarlik mens te wees nie, hulle is nuwe mense in soverre hulle dit reeds in Christus is, maar dit ook daagliks meer en meer moet word. 'Hierdie mens is egter nooit perfek of gearriveerd nie, maar binne die dimensie van die eskatologie en die toekoms is hy steeds ' $n$ swerwer in die hede op pad na sy ewige vaderhuis of die ewige verderf' (Coetzee 1996:19).

\subsection{Die kind as geheiligde}

'n Antropologie wat net op die Christologie gefundeer is, loop die gevaar om lewensvreemd en mensvreemd te word. Heitink (1977:108) is daarom reg as hy daarna streef om ' $n$ trinitariese visie op die mens te bied: die mens as skepsel van God die Vader, as nuwe mens in Christus en as geheiligde mens of as humanitêre in die Heilige Gees. In sy bipolêre benadering verbreed hy die pole sonde en genade tot skepping en herskepping en skep ruimte vir die konsensus wat tussen die teologie en die psigologie noodsaaklik is (Coetzee 1996:21).

Omdat geloof alleen moontlik is deur die werking van die Heilige Gees (Nederlandse Geloofsbelydenis, artikel 24; Heidelbergse Kategismus, Sondag 25 vraag en antwoord 65), is dit moontlik dat kinders ten volle kan glo en ten volle deel kan hê aan al die gawes wat God in Christus deur die Gees vir sy eiendom bestem het. Deur die werking van die Heilige Gees is die mens 'n wese met 'potensiaal'. Eduktief gesien is die potensiaal van die mens psigo-fisies van aard. Vanuit 'n trinitaries gefundeerde antropologie is hierdie potensiaal egter garismaties van aard (Coetzee 1996:22). Die mens het die opdrag om in Christus te glo, om gehoorsaam aan God te wees en om die garismata in hulle lewe te laat realiseer.

\subsection{Die kind as verbondskind}

Hoewel die kerk nie sy teologie en daarmee saam sy antropologie net op die verbondsteologieë behoort te baseer nie (Venter 1984:66), vorm die verbond waarskynlik een van die grondstrukture van God se verhouding met die mens (Berkhoff 1969:59). 'Met die begrip verbond wil die kerk die belydenis uitspreek dat God as die Gans Andere uit liefde en goedheid Homself aan die mens gee, Hom neerbuig na die mens; uit sy heiligheid tree om met die mens 'n ewige verhouding te begin' (Robbertze 1995:4). Dit is die wil van God dat die verbonde wat Hy by verskeie geleenthede met sy volk gesluit 
het, prakties sal realiseer, veral in die samekomste van die verbondsgemeenskap (Schutte 1996:4). Die Reformatoriese kerke aanvaar dat die kind net soos die volwassene ten volle deel het aan die verbond (Nederlandse Geloofsbelydenis, artikel 34; Heidelbergse Kategismus, Sondag 27, vraag en antwoord 74; Doopformulier). Die Doopformulier vat in een van die vrae wat aan die ouers gevra word, die Reformatoriese beskouing ten opsigte van die kinderdoop baie goed soos volg saam: 'Aanvaar u dat ons kinders wat van hulle eerste lewensoomblik sondig is en in sonde gebore word, in die ellende van die sonde onder die cordeel van God verkeer? Bely u dat hulle nogtans deur Jesus Christus verlos is en daarom as lidmate van sy gemeente gedoop behoort te wees' (Diensboek NHK 1983:58). Van Aarde (1991:697) toon baie duidelik aan dat die Reformatoriese beskouing oor die kind, soos dit tot uitdrukking kom in die klassieke doopformulier, die resultaat is van deeglike eksegese van die Nuwe Testament. Hy kom tot die konklusie: 'dat die kind van gelowiges op geen wyse minder kind van God is as die ouers self nie'.

\subsection{Die plek en funksionering van die kind in die Ou-Testamentiese geloofs- gemeenskap}

Kinders is beskou as 'n besondere gawe van die Here (Ps 127:3; 128:4). In die Ou Testament word dikwels oor 'n ouer se verlange na en vreugde oor die geboorte van 'n kind melding gemaak (Gen 30:22; 1 Sam 1:11). Die besondere waarde wat aan kinders geheg is, blyk ook uit die feit dat die offer van kinders verbied is (Lev 20:2-5). Hierdie wetgewing is waarskynlik genoodsaak op grond van die feit dat die offer van kinders dikwels ' $n$ verlengstuk was van die algemene praktyk wat in die antieke wêreld voorgekom het dat kinders weggegooi of doodgewoon uitgesluit is. Van Aarde (1991: 698) toon oortuigend aan dat dit feitlik algemene gebruik w's dat veral kinders met een of ander gebrek, weggegooi is.

In Israel word die besnydenis op 'n baie jong ouderdom of die manlike babas toegepas. Die besnydenis het so gedien as opname in die nasionale en daarmee geïntegreerde kultiese gemeenskap (Oepke 1967:647). Die kinders kan o:s daarom sê is van baie jonk af gereken as deel van God se verbondsvolk (Lindeque 1995:1). Barnard (1981:100) ordeel dat kinders en vrouens nie aan die gewone ku'tiese handelinge by die heiligdom en later in die tempel kon deelneem nie. Selfs in die Sinagoge kon hulle slegs op die gallery as waarnemers funksioneer (Beukes 1993:15). Volgens van Staden (1991:1) is die primêre grond vir hierdie uitsluiting gegrond op hulle verstaan van die shema. Die relasie tussen God en mens is grootliks gereël deur die shema wat saamgestel is uit drie gedeeltes van die Skrif naamlik Deuteronomium 6: 4-9; 11:13-21; Numeri 15:37-41. Uit hierdie belydenis dat God die enigste Here is, is afgelei dat slegs hulle wat deel is van sy volk en in die besonder net hulle wat sy wet volkome 
onderhou, voor sy aangesig kan verskyn. Psalm 15:1-5 en 24:3-4 sou beskrywend wees van hierdie situasie. Aangesien die heiligdom, die tempel, God se besondere woning is, kan hier net ontmoeting plaasvind tussen God en sogenaamde heilige mense. Enige mens met 'n gebrek, enige iemand uit 'n heidennasie en selfs vrouens en kinders, het deel gevorm van die mense wat uitgesluit is. Hierdie heiligheidsbeskouing is ook deurgetrek na die alledaagse lewe. Dit het meegebring dat dieselfde kategorieë wat uit die tempel uitgesluit is, sondermeer ook uit die samelewing geskuif is en beskryf is as sondaars (Van Staden 1994:2). Aan die ander kant was dit nie vreemd dat kinders saam met hulle ouers aan sommige godsdienstige feeste deelgeneem het nie (Beukes 1983:23).

Volgens Van Aarde (1991:702-703) het daar 'n geleidelike verruiming plaasgevind. Hierdie verruiming betrek beide die tempelgangers en die ruimte waarbinne die ontmoeting tussen God en mens kon plaasvind. In Deutro-Jesaja bestaan die moontlikheid baie sterk dat ontmoeting met God buite die tempel moontlik is (Jes 66:1). In die boek Nehemia en die Kronistiese skrywers word die volksvergadering verruim, sodat dit ook vrouens en kinders kan insluit. In die tussen-testamentêre literatuur word op verskeie plekke melding gemaak dat God ook buite die tempel, dit wil sê daar waar die mense wat normaalweg uitgesluit was, ontmoet kan word. Dit was veral die Qumran gemeenskap wat sterk klem op die ontmoeting tussen God en mens buite die tempel gelê het. Hulle het selfs so ver gegaan om die tempel as ontmoetingsplek met God af te skryf (Van Aarde 1991:703).

Die familie het gefunksioneer as 'n religieuse eenheid wat die tradisies moes bewaar en oordra aan die nageslag deur onderrig en voorbeeld (Van Staden 1994:3). In die familie was die opvoeding van die kind veral die verantwoordelikheid van die ouers. Dit moes deel van die gesin se alledaagse lewe uitmaak (Deut 6:7-9, 20-21, 32:7, Ps 78:3-6). Die Woord van God moes deur die ouers self geglo en geleef word en hulle moes die kinders opvoed in die religieuse en historiese erfenis van die volk. Die kern van hierdie inhoud was God se heilshandelinge soos dit veral in die geskiedenis van die volk na vore gekom het. Naas God se groot handelinge, moes die kinders ook leer om al die etiese voorskrifte wat vir die Joodse volk geld te onderhou, dit wil sê die aanleer van die regte lewenswyse (Lindeque 1995:2). Kinders het opgegroei in 'n totale religieuse milieu (Beukes 1983:24). Die onderrig het dikwels plaasgevind met bepaalde konkrete gebeure as vertrekpunt. So byvoorbeeld moes die besoek aan 'n historiese baken en die gebruik van die pasga die vader oproep om met sy kind daaroor te praat, veral as die kind daarna sou vra (Jos 4:21-22; Eks 12:26-27; 13:7-8, 14). 
2.6 Die plek en funksionering van die kind in die Nuwe-Testamentiese geloofsgemeenskap

Getuienis dui daarop dat kinders in die antieke tyd in Griekeland, Rome en Egipte van jongs af reeds ingelyf is in en deelgeneem het aan die kultus (Oepke 1967:643-645). Hoewel daar as gevolg van hierdie Hellenistiese invloede vir die kind 'n positiewe waardering begin ontstaan het, was dit nog steeds die Ou-Testamentiese en Judaistiese beskouings wat in die tyd van die ontstaan van die Nuwe Testament die bo-toon gevoer het (Van Staden 1994:5). Met die aanbreek van die Nuwe-Testamentiese periode, soos reeds gesê, was dit algemene gebruik dat vrouens, kinders en ander kategorieê mense van die tempel en eintlik die aanvaarding in die alledaagse gemeenskap, uitgesluit was. Van Aarde (1991:701) beskryf hierdie situasie soos volg:

Die Fariseïese replisering van die tempelgemeenskap na die alledaagse lewe het die religieuse implikasies gehad dat sosiale ostrasisme gelegitimeer is met Godsvervreemding. Sosiaalveragtes (soos stommes, dowes, blindes, melaatses, gestremdes, tollenaars en nie-Jode) is nie net sondaars genoem nie, maar dikwels ook duiwelbesetenes. Diesulkes kon in beginsel volgens die Judaïsme nie God se teenwoordigheid ervaar nie, omdat hulle nie die tempel kon betree buiten die voorhof van die heidene nie. Volgens Fariseiese maatreëls is gevolglik geen gemeenskap met sondaars in die daaglikse lewe geduld nie. En dit het veral vir die gemeenskaplike maaltyd gegeld en die hieruit voortspruitende normale sosiale versorging.

Jesus Christus het egter 'n radikale verandering gebring met betrekking tot die kind en al die geostraseerdes van die samelewing. Hy slaan die kind so hoog aan dat Van Aarde (1991:692) en ander Hom beskryf as die ontdekker van die kind. 'Dit was Jesus wat die eienskappe van wat tipies kindwees is, as eksemplaries uitgewys het van wat dit is om gelowig te wees'.

Die Matteus-evangelie teken Jesus as persoon wat op 'n besondere wyse vir die geostraseerdes omgegee het. Op verskillende plekke word melding gemaak dat Hy kreupeles en blindes genees het. In Matteus 21:14 word self melding gemaak van die feit dat Hy hulle in die tempel genees het. Die metafoor skaap word deur Matteus gebruik as beskrywing vir die 'verlore skape van die huis van Israel' (9:36 \& 18:12); die kindertjies (10:6) en die kleintjies (18:6). Van Aarde (1991:704) toon oortuigend aan dat Jesus juis in die besonder vir diegene Immanuel is. Matteus verhaal ook dat met 
Jesus se sterwe die voorhangsel van die tempel middeldeur geskeur het (27:51) en dat kinders Jesus in die tempel as die seun van Dawid geëer het (21:15). Anders as die Esseners het Jesus nie die tempel as woonplek van God afgeskryf nie. Hy het dit as sodanig behou, maar die ruimte waar God mense wil ontmoet, nog verder verbreed. 'Jesus vervang met ander woorde nie die tempel soos die Esseners beoog het nie; net soos die Fariseërs repliseer Hy die tempelmaatreëls, maar anders as die Fariseērs, verruim Hy die tempel met die gevolg dat die sosio-religieuse randpersoon by maaltye by huise (Mark 12:39) sowel as in die tempel (Mark 12:41-44) welkom is' (Van Aarde 1991:704).

Veral sedert die Reformasie het Markus 10:13-16, die sogenaamde 'kinder-evangelie, in Reformatoriese kerke ' $n$ belangrike plek ingeneem. Die Heidelbergse Kategismus gebruik dit as een van die motiveringstekste vir die kinderdoop. Dit is in die Zürichse doopformulier opgeneem en is as sodanig aan die ouers net voor die doop van 'n kind voorgelees. Nuwe-Testamentici gebruik nie meer hierdie gedeelte as motivering vir die doop nie, maar sien dit nog steeds as 'n gedeelte wat 'n besondere boodskap bring met die oog op die plek van die kind in die kerk. Hierdie gedeelte word vandag eerder gesien as mikrovertelling wat 'n sterk coreenkoms toon met ander wondervertellings wat veral gedien het om Jesus se besondere houding teenoor die geostraseerdes en hier dan veral die kinders te beskryf. Jesus gee hier baie duidelik te kenne dat Hy die kinders wil akkommodeer en dat hy volkome teen die 'uitsit van kinders uit die huis' is (Van Aarde 1991:705-708). Die boodskap van die 'kinder-evangelium' word soos volg deur Schmithals (1986:448, soos aangehaal Van Aarde 1993:707) beskryf:

Die Kinder haben vollen Anteil am Heil der Gottesherschaft, das nicht von der menschlichen Leistung abhangt. Nimmit aber Gott sie vorbehaltlos an, dan folgt daraus mit aller Selbstverständlichkeit ihre Annahme durch die von Gott gleichfalls angenommenen Menschen. Wer gleichwertiges Glied der Gemeinde ist, musz auch im Haus voll anerkannt werden, ein Schlusz, der um so selbstverständlicher ist als Haus und Gemeinde in der Zeit der Hausgemeinden ohne - dies eine Einheit bildeten. Als Teil der Haustafel sagt unser Text also:

Was Gott angenommen hat, darf der Mensch nicht verstoszen oder verachten. Die Kinder sind vollwertige Glieder der christliche Gesellschaft. 
Die Lukas-evangelie is 'n poging om aan te toon dat Jesus nie net gekom het om die mens te red van sonde en dood nie, maar om ook die geostraseerdes, wat die kinders insluit, weer hulle regmatige plek in die tempel en in die samelewing te gee (Van Staden 1991:4). Lukas roep sy lesers op om compassionate te wees. Jesus Christus stel self in hierdie verband die voorbeeld deur die rol van 'n slaaf in te neem en te deel met die uitgeworpenes. Die Jesus van Lukas het volgens Van Staden uiteindelik dieselfde doel as die Fariseërs naamlik: 'replicating the temple purity system in the lives of the people. There is a marked difference, though in that Jesus scheme provides for the incorporation of the social outcasts among those who are deemed acceptable to God, while in the scheme of the Pharisees they are excluded' (Van Staden 1991:6).

In Handelinge word dit duidelik dat die uitsluiting van sekere mense uit die geloofsgemeenskap deur die werk van Jesus Christus beëindig is. 'n Man wat van sy geboorte af verlam is, word genees en direk daarna gaan hy die tempel binne (Hand 3: 1-10). In Samaria word uit die geledere van heidene siekes genees en bose geeste uitgedryf (Hand 8:7). 'n Ontmande man uit Etiopië het meteens die voorreg om die evangelie van Jesus Christus te hoor en gedoop te word (Hand 8:26-40). Die huisgesinne van heidene, Kornelius en Lidia hoor die Evangelie en word gedoop (Hand 10: 48; 16:15). Op grond van Christus se lyde en sterwe het die belofte wat God eenmaal aan Abraham gemaak het, waar geword: 'Wat God belowe het, is vir julle en vir julle kinders en vir almal wat daar ver is, vir almal wat die Here ons God na hom toe sal roep' (Hand 2:39).

Hoewel die saak van kinders in die Nuwe-Testamentiese Briewe en Openbaring nie pertinent na vore kom nie, is die vermelding van kinders in gedeeltes soos Efesiërs 6:14 en Kolossense 3:20 'n duidelike aanduiding dat kinders deel was van die geloofsgemeenskap waar die briewe voorgelees is.

\section{Kerkregtelike posisie van die kind in die Nederduitsch Hervomde Kerk Van Afrika}

Die wyse waarop 'n kerk kerkregtelik oor die kind dink, sal in 'n baie groot mate bepalend wees vir die wyse waarop die bepaalde kerk kinders kerklik bedien.

Die Kerkwet van die Nederduitsch Hervormde Kerk van Afrika handel in artikels 3, 17 en 18 oor lidmaatskap van die Kerk (Kerkwet NHKA 1993:3,7). In artikel 3 word 'n drieledige onderskeiding in lidmaatskap gemaak: gedoopte lidmate, belydende lidmate en lidmate wat nie gedoop of belydenis van geloof afgelê het nie, maar op grond van hulle geboorte uit gelowige ouers gereken word as lidmate van die kerk. In hierdie artikel word net verskillende kategorieë lidmate onderskei. In artikel 17 en 18 verander die woordkeuse. In artikel 17 word gesê die kategese moet lei tot openbare belydenis van geloof, die gebruik van die sakramente en die verantwoordelike lidmaat- 
skap van die Kerk. Hierdie artikel skep die indruk dat jy eers lidmaat word nadat jy belydenis van geloof afgelê het. Artikel 18 bevestig hierdie indruk as dit stel dat diegene belydenis van geloof aflê wat te kenne gegee het dat hulle in die gemeente opgeneem wil word. Die implikasie is dat hierdie mense al die jare van hulle geboorte nie werklik in die gemeente opgeneem en lidmate van die kerk was nie.

Die vraag is wanneer het die gedagte ontstaan dat jy eers lidmaat word en in die gemeenskap van die gelowiges opgeneem word wanneer jy belydenis van geloof gedoen het? Dreyer (1994:525) toon baie duidelik aan dat in die oorspronklike Geneefse kerkorde daar nie sprake van was nie. Ook Calvyn het nie geloofbelydenis nie, maar die doop gesien as die inlywing in die kerk: 'De doop is een teken der inwijding, waardoor wij tot de gemeenschap der kerk worden aangenomen, opdat wij, in Christus ingeplant, onder Gods kinderen word gerekend' (Calvyn soos aangehaal Dreyer 1994:525). Dit was egter Bucer wat teenoor Calvyn die geloofbelydenis gesien het as die werklike opname in die gemeenskap van die gelowiges (Pont 1991:440). Die latere kerkordes het hierdie beskouing behou en in die Nederduitsch Hervormde Kerk van Afrika loop dit deur tot en met sy jongste Kerkwet.

Op grond van goeie teologiese gronde konkludeer Dreyer (1994:527) 'Die kind word met sy doop lidmaat van die kerk: deur dit te verwaarloos in ons teologiese nadenke en in die kerkwet, verduister ons die heilsbetekenis van die doop vir die gelowige (kind)'. Die rede waarom die Kerk deur die eeue Bucer se beskouing oor lidmaatskap van die kerk gehandhaaf het, is waarskynlik nie bewustelik op prinsipiële gronde nie, maar bloot onnadenkend. Hierdie onnadenkendheid se gevolg is dat kinders tot vandag toe eers as werklike lidmaat beskou word nadat hulle belydenis van geloof afgelê het.

\section{PSIGOLOGIES-SOSIOLOGIESE ASPEKTE}

Alhoewel elke kind uniek is en kinders daarom meer anders as eenders is, is daar tog 'n aantal karakteristieke van kinders wat ooreenstem (Beukes 1983:125). Olivier (1985: 246-257) noem die volgende gemeenskaplike eienskappe van kinders: kindwees impliseer volwasse-wordend wees, die kind is intensionaliteit, die kind hunker na geborgenheid, die kind is spelend in die wêreld, die kind beleef slegs die sinvolle as positief en kinders deurloop sekere lewensfases voordat hulle volwassenheid bereik. Elkeen van hierdie eienskappe het besondere betekenis vir die kind in die erediens.

\subsection{Die kind is volwasse-wordend}

Omdat die kind nog nie volwasse is nie, kan hy/sy nog nie selfstandig optree nie. Kinders het gevolglik behoefte aan begeleiding met die oog op hulle gang deur die wêreld, veral wat besluitneming betref. Dit beteken nie dat die kind sondermeer ' $n$ 
onbekwame, ontwikkelende, rigtingsoekende wese is nie (Erasmus 1996:1). In teenstelling met outoritêre figure wat kinders deurlopend degradeer, stel Pretorius dat die kind eerder beskryf moet word as 'n unieke inisiatief van verhoudinge

... hy is steeds nuwe moontlikheid, hy kan kies en hy kan rekenskap gee, hy moet eksisteer tot selfverwerkliking. Hy is persoon, intensionaliteit, dasein, mitsein, gees. Hy is altyd (pedagogies) gesitueerd. Die kind as ontwikkelende entiteit-persoon in die volle sin van die woord, sal binne die erediens geakkommodeer moet word, ten einde ook sy singewing binne sy betrokke religieuse milieu, met die wording van sy menswees te assimileer'.

(Pretorius 1972:115)

Indien die diskrepansie voortduur, mag die kind homself binne die erediens as vreemdeling beleef, wie se belange en belangrikheid nie alleen misken word nie, maar later self geen intra-psigiese motivering sal delf om religieus betrokke te raak nie (Erasmus 1996:1).

\subsection{Die kind is nie ' $n$ speelbal in die hand van die volwassene nie}

Die kind is medebepalend. Die kind is nie 'n blote objek nie, maar mede-subjek. 'Niemand kan 'n kind leer wat hyself nie wil leer nie' (Olivier 1985:249). Goeie leerinhoude en goeie aanbiedingstrategieë waarborg nie sondermeer betrokkenheid nie, maar deur swak inhoude en swak aanbiedingstrategieë word definitief verhinder dat leer plaasvind. Kinders is voortdurend besig om te beleef. Slegs dit wat vir hulle sin maak en kognitief en affektief vir hulle vatbaar is, beleef hulle as positief. Dit wat vir hulle sinloos en kognitief-affektief bokant hulle vermoë is, gaan verlore, afgesien van die hoeveelheid herhalings daarvan. 'Sinvolle aanbieding na inhoud en vorm word onthou, selfs na 'n eenmalige blootstelling' (Beukes 1993:180). As kinders gevoelsmatig beleef dat die inhoud en die wyse van aanbieding vir hulle gerusstellend, vertroostend en stabiliserend van aard is, beklee hulle dit met positiewe sin en rig hulleself intensioneel met openheid tot verdere verkenning. Word hulle nou op gereelde basis onderwerp aan eredienste wat hulle in die meeste opsigte as sinloos beleef, bou hulle 'n bepaalde ervaringsbesit op ten aansien van die inhoud as synde nutteloos vir hulle. Sulke kinders onttrek en wil hulleself nie intensioneel rig nie. Hulle laat hulle nie verder onderrig nie (Olivier 1985:251). 


\subsection{Kinders het 'n baie groot behoefte aan geborgenheid op hulle lewensgang} Hierdie geborgenheid word vir kinders geskep deur die atmosfeer in die erediens en rondom die erediens. Die belangrikste skeppers van hierdie geborge atmosfeer is die erediensgangers, veral die ouers en die liturg. Laasgenoemde is veral belangrik omdat kinders hulle slegs laat leer deur iemand wat daarin slaag om hulle vertroue te wen en vir hulle 'n gevoel van geborgenheid gee (Olivier 1985:252). Die predikant wen hierdie vertroue nie net op die kansel nie, maar deur sy totale manier van menswees voor God en voor ander mense (Van der Merwe 1995:16). Dit is veral die predikant se omgee vir mense, maar veral vir kinders wat 'n oorheersende rol speel. Die manier waarop 'n gemeente voor, tydens en na die erediens funksioneer is van die allergrootste belang vir die deelname van die kinders aan die erediens. 'n Warm, geborge atmosfeer lok, 'n koue kliniese atmosfeer stoot weg.

\subsection{Kinders bevind hulle in verskillende lewensfases}

Hoewel hierdie fases nie in waterdigte kompartemente ingedeel kan word nie, het elke fase tog besondere kenmerke. Met die oog op ons tema word hoofsaaklik aandag aan die vroeë kinderjare, middelkinderjare en laatkinderjare gegee. In die vroeëkinderjare (5-7 jaar) stel die kleuters hoofsaaklik belang in die konkrete. Slegs aspekte wat betrekking op die hier en die nou het, spreek hulle aan. Hulle konsentreer op die bekende en nie op die belangrike nie. Hulle dink met hulle hart en nie met hulle verstand nie. Hulle begripswêreld is net so breed soos hulle ervaringsveld. Tydvakke speel in hulle lewe nie 'n belangrike rol nie (Olivier 1982:7). Die kinders in hierdie fase is baie sterk nabootsers.

Hulle godsdiens word daarom hoofsaaklik bepaal deur hulle opvoeders. Die voorstelling wat hulle van God het, is gelyk aan die voorstelling wat hulle van hulle ouers het (Van Wyk 1976:9): Saam met die eerste lewensjare is hierdie van die belangrikste vormingsjare. Die grootste behoefte van kinders in hierdie jare is liefde en geborgenheid. Hulle ouers en veral die moeder speel nou die belangrikste rol (Beukes 1983: 132).

In die middelkinderjare (8-10 jaar) ontwikkel kinders se denkvermoë baie sterk van die spesifieke na die meer algemene. Hulle begin om 'n samehangende kognitiewe sisteem te ontwikkel. Dit beteken dat hulle die vermoë ontwikkel om die hede met die verlede te verbind en om sekere aspekte van hulle wêreld met mekaar in verband te bring. Hulle begin om 'n saak van verskillende kante te beskou en kom agter dat mense verskillende standpunte het (Van Biljon 1994:1). Erasmus (1996:2) maak die afleiding dat laerskoolkinders reeds die vermoë het om verbande tussen die Christusgebeure en die hede - hulle wêreld, hulle ouerhuis, ensovoorts te trek. Hy vra heel tereg die vraag op welke manier die kerk hierdie kinders die geleentheid bied om fusie 
tussen hulle intellektuele verstaan en hulle ervarings-belewenis te maak. Die kinders ontwikkel nou belangstelling in groepaktiwiteite, wat hand aan hand loop met kreatiwiteit en vindingrykheid. 'Kinders leer veral deur te handel, deur nuwe ervaring, deur te debatteer en te argumenteer. Die kind leer en hou belangstelling deur middel van deelnemende aktiwiteite' (Erasmus 1996:2). Van Biljon (1995:3) sluit by hierdie gedagtegang aan: 'kinders in hierdie jare leer deur te handel, met ander woorde die handeling van die kind bepaal in 'n groot mate die kennis waartoe hy kom. Verbale onderrig is vir die jong skoolkind gewoonlik oneffektief'.

In die laatkinderjare (11-13 jaar) begin kinders om sekere eienskappe van volwassenheid te vertoon. Hulle begin abstrak dink. Hulle raak krities ingestel. Hulle is baie sterk groepgebonde. Op hierdie stadium vereenselwig hulle hulle met bepaalde norme om dit in die fase van adolessensie weer sterk te bevraagteken. Stewige fondamentlegging voor die laatkinderfase is daarom van die allergrootste belang (Beukes 1983:139). Omdat hierdie kinders besig is om uit die kinderfase uit te beweeg en reeds met een voet in die adolessensie fase is, is hulle veral baie krities ingestel vir aanbiedingswyses wat lê op die vlak van klein kinders. In hierdie fase is kinders baie sterk groepgebonde. Kinders ontwikkel geleidelik van egosentristies na sensitiwiteit vir ander. Hoe meer kinders van hulle eie eksistensie bewus raak, hoe meer stel hulle hulle in ten opsigte van die wisselwerking tussen die 'ek' en die 'ander'. Kaplan en Sadock (1995:47) beklemtoon die belangrikheid van ontwikkelingslandmerke van kinders ten opsigte van hulle emosionele en sosiale gedrag en dat dit as determinante vir verdere ontwikkeling dien. 'Empathy and a concern for others begin to emerge early in the middle years; by the time children are 9 or 10 , they have well-developed capacities for love, compassion, and sharing' (kyk ook Van Biljon 1995:3). 'Dit spreek vanself dat die sosiale en emosionele sensitiwiteit van die laerskoolkind as ' $\mathrm{n}$ ryk bron van potensiaal en energie binne sy religieuse ervaringswêreld ontgin kan word. Is die teendeel nie juis vandag waar dat daar as gevolg van argaïese, gefikseerde metodiek juis 'n sosiale en emosionele demper op die kind in die erediens geplaas word nie (Erasmus 1996:2)?

\section{DIE LEEFWÊRELD VAN DIE LAERSKOOLKIND}

Elke kind is 'kind van sy eie plek, eie tyd en eie omstandighede'. Met die oog op verrekeninge van kinders in die erediens, sal deeglik gekyk moet word na die milieu waarin kinders opgroei. Kinders groei vandag op in 'n milieu waar 'n groot hoeveelheid vorme, norme en oortuigings funksioneer. Elkeen van hierdie aspekte het ' $n$ invloed op hulle. Ouerhuise en kinders wat in 'n godsdienstige milieu opgroei, is nie meer vanselfsprekend nie (Van Niftrik s a:7). Daar kan selfs 'n boek geskryf word met die titel 'erwachsenwerden ohne Gott' (Nipkow 1987). 
Steenmeijer-Van Rij (1969:20) het teen die einde van die sestigerjare 'n aantal tendense opgenoem wat tot vandag algemeen geldend is. Die belangrikste is die volgende:

die waarheid staan nie meer vas nie; die Christelike godsdiens word slegs beskou as 'n godsdiens naas ander godsdienste; die belangstelling in die hiernamaals het geheel en al vervaag; die mens se eie behoeftes het die bepalende faktor van sy lewe geword; eksperimentering kom op feitlik elke terein van die lewe voor en die portuurgroep word 'n baie belangrike faktor waarmee voortdurend rekening gehou moet word.

By die lys kan die volgende nog bygevoeg word: ' $n$ funksionele materialistiese ingesteldheid; ' $n$ beskouing dat die kerk se opsies te staties, te outokraties en te histories is; oorvol programme en gevolglik vir feitlik niks meer tyd nie; anonimiteit; 'n beskouing dat godsdiens ' $n$ private aangeleentheid is, multikulturele gemeenskappe en so ' $n$ algehele verstedeliking dat van feitlik alle mense gesê kan word dat die stad in die mens is.

Op Suid-Afrikaanse bodem is dit veral die studie van Boshoff (1990:21) wat besondere bruikbare gegewens op die tafel geplaas het. Hy toon die volgende as feitlik algemene tendense van die Suid-Afrikaanse samelewing aan: enkelouers; afwesige vader en moeder; groot diversiteit in waardesisteme; afwesigheid van uniforme lidmate en gemeenskappe; bevraagtekening en selfs omvêrgooi van tradisies; toeganklikheid van ander kulture en godsdienste en groot onsekerheid oor die toekoms. In die hantering van die jeug sal ook rekening gehou moet word met algemene tendense van die post-modernisme wat reeds deel van die Suid-Afrikaanse samelewing se denkpatrone en leefpatrone geword het. Die belangrikste tendense wat verreken moet word, is waarskynlik die volgende: anti-institusionalisme, relatiwisme, die moontlikheid van die bestaan van twee waarhede naas mekaar, die regte van kinders en vrouens. Hierdie postmodernistiese tendense moet volgens Steenkamp (1996:16) nie net as 'n bedreiging gesien word nie, maar juis as ' $n$ besondere geleentheid.

\section{GEVOLGTREKKINGS}

Uit die Bybels-dogmatiese gegewens is dit duidelik dat op grond van Jesus Christus se koms kinders op geen manier minder die eiendom van God is as volwassenes nie. Die feit dat kinders in die verlede eers as lidmate beskou is nadat hulle belydenis gedoen het, word deur geen kerkregtelik-prinsipiële gronde gesteun nie. Op grond van bogenoemde, behoort kinders as teikengroep in die erediens ten volle verreken te word. Met die besondere aard van die laerskoolkind moet in elke erediens rekening gehou word. Die vraag kan tereg gevra word of hierdie kinders se besondere fasekenmerke 
nie meebring dat daar in die kerk van tyd tot tyd eredienste gehou word waar hierdie kinders as kern teikengroep in die fokuspunt moet staan nie (die sogenaamde kind-gerigte eredienste).

\section{Literatuurverwysings}

Barnard, A C 1981. Die erediens. Pretoria: NG Kerkboekhandel.

Barnard, A C 1988. Erediens en prediking met die oog op die bereiking van kinders. NGTT 29/4.

Beukes, M J du P 1983. Kategese: 'n Handleiding vir kategete. Pretoria: Kital. - 1993. Erediens, I. Pretoria: Kital.

Boshoff, H 1990. Samelewingsveranderinge en die kerk in die negentigerjare: Moontlike implikasies. Potchefstroom: Instituut vir toekomsstudies.

Buitendag, J 1995. Die kind in die kerk (dogmaties beskou). Stellenbosch: Ongepubliseerd.

Capon, A \& Capon, E 1967. The church and the child towards a Christian upbringing. London: Hodder \& Stoughton.

Coetzee, J 1996. Antropologiese insigte vir 'n pastorale teorie binne die hermeneutieskommunikatiewe handelingsperspektief. Pretoria: Ongepubliseerd.

Dreyer, W A 1994. Die kerkregtelike posisie van die kind in die Nederduitsch Hervormde Kerk van Afrika, met besondere verwysing na lidmaatskap, doop, nagmaal en tug. HTS 50/3, 522-530.

Du Rand, J J F 1982. Skepping, mens, voorsienigheid. Pretoria: NG Kerkboekhandel. Erasmus, J 1996. Die laerskoolkind in die erediens, psigologies-sosiologiese aspekte. Pretoria: Ongepubliseerd.

Kaplan, H I, Sadock, B J, Grebb, J A 1995. Synopsis of Psychiatry: Behavioural Sciences and clinical psychiatry. USA: Williams \& Wilkins.

Lindeque, G C 1995. Wie is die kind in die erediens? Die Ou Testament se siening. Pretoria: Ongepubliseerd.

Louw, D J 1989. Die ontwerp van 'n teologiese antropologie as basisteorie vir 'n effektiewe pastorale bediening in Smuts, A J (red) Predikant en pastorale praktyk: Teologiese en sielkundige perspektiewe. Pretoria: Academica.

Nipkow, K E 1987. Erwachsenwerden ohne Gott? Gottes Erfahrung im Lebenslauf. München: Kaiser.

Ott, H 1981. Die Antwort des Glaubens. Stuttgart: Kreuz.

Olivier, S E 1982. Die kind in kategese. Referaat, Predikante vergadering NHKA: Ongepubliseerd.

Olivier, M 1985. Die kind in die kategese, in Smuts, A J (red), Die woord aan die werk. Pretoria: NG Kerkboekhandel. 
Pont, A D 1991. Historiese agtergronde van ons kerklike reg, Deel 2. Pretoria: Kital. Pretorius, J M W 1972. Grondslae van die pedoterapie. Johannesburg: McGraw-Hill. Robbertze, M D 1995. 'n Dogmatiese besinning oor wie die kind in die erediens is. Pretoria: Ongepubliseerd.

Schutte, P J W 1996. Die verbond. Witbank: Ongepubliseerd.

Steenkamp. L J S 1995. Kerk en kultuur in 'n post-moderne samelewing. Pretoria: Ongepuliseerd.

Steenmeijer van Rij, M C 1969. Godsdienstige opvoeding in deze tijd: Benadering van 8-9 en 10-jarigen in de kinderdienste. Den Haag: Boekencentrum.

Thurneysen, E 1957. Die Lehre von der Seelsorge. Zürich: Evangelischer Verlag.

Van Aarde, A G 1993. 'n Nuwe-Testamentiese perspektief op die kind. HTS 47/3, 685-715.

Van Biljon, J A 1994. Psigologie van die kind. Pretoria: Ongepubliseerd.

Van der Merwe, M 1995. Nuwe treẻ saam met God. Riglyne en programme oor spiritualiteit en gemeentevernuwing. Kaapstad: Lux Verbi.

Van Loggerenberg, N T 1982. Kinderdienste. Die Voorligter 45/11, 37-38.

Van Niftrik, G C s a. Het geloof der kinderjaren in die branding van het latere leven. Nijkerk: Callenbach.

Van Staden, P 1991. Compassion - The essence of life: A social-scientific study of the religious symbolic universe, reflected in the ideology/theology of Luke. Pretoria: University of Pretoria. (HTS Suppl 4.

1994. Wie is die kind in die erediens? Nuwe-Testamentiese perspektiewe. Johannesburg: Ongepubliseerd.

Van Wyk, J H 1976. Kategetiese Onderrig - metodiese riglyne. In opdrag van die sinodale deputate vir katkisante van die Gereformeerde Kerk in Suid-Afrika. Potchefstroom: Pro Rege.

Venter, P M 1984. Hoofsaak van die Bybel vir kategese. Theologia Viatorum 12/2, 74-85. 